\title{
Detection of subclinical mastitis in dromedary camels (Camelus dromedaries) using somatic cell counts, california mastitis test and udder pathogen
}

\author{
S.K. Saleh ${ }^{1 *}$ and B. Faye ${ }^{1,2}$ \\ ${ }^{1}$ Camel and range Research Center, P.O. Box 322, Al-Jouf, Sakaka, Saudi Arabia; ${ }^{2}$ CIRAD- \\ ES, Campus international de Baillarguet, TA C/dir B 34398 Montpellier, France
}

\begin{abstract}
A total of 120 quarter milk samples from 30 clinically healthy dromedary camel from Al-Jouf, Saudi Arabia were cultured to detect subclinical udder infection. The milk samples were screened by somatic cell count (SCC) and California mastitis test (CMT). Gram-positive cocci were the dominant recovered udder pathogen. The mean value of SCC was 125,000 cells/ $\mathrm{mm}^{3}$. Infected quarter had generally higher mean values for SCC and CMT scores. Both SCC and CMT were of value in predicting the infection status of the udder.
\end{abstract}

Key words: Dromedary camel, udder, milk, somatic cell, bacteria.

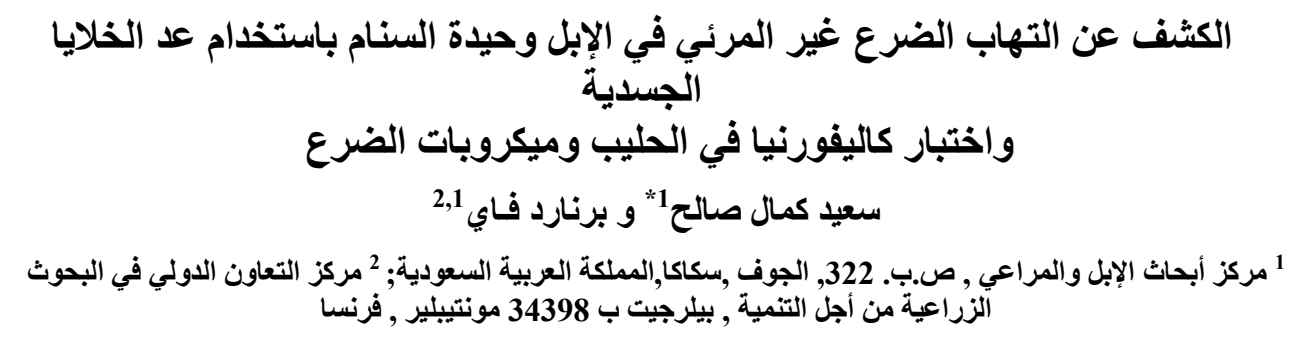

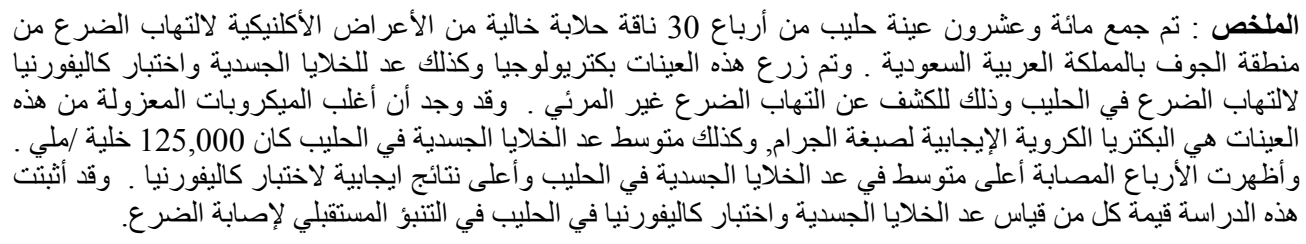

*Corresponding Author, Email: sa2005ka@hotmail.com 


\section{Introduction}

In spite of its living in harsh environments of semiarid and arid zones, the dromedary camel is able to produce milk in valuable quantity (Schwartz and Dioli, 1992; Faye, 2005). However, as for other dairy animals, dromedary camel could be affected by udder infection as mastitis, a complex disease occurring worldwide among dairy animals, with heavy economic losses largely due to clinical and subclinical mastitis. The last requires indirect means of diagnosis (Matofari et al., 2003). Evidence indicates that subclinical mastitis causes suffering of the animal, reduce milk yield, alters milk properties, impairs preservation and processing and is a public health concern for consumers of camel milk (Fthenakis and Jones, 1990; Tibary and Anouassi, 2000). Very little is known about mastitis concerning their aetiology and occurrence in Camelidae (Abdel Gadir et al., 2006; Kalla et al., 2008). However, cases of mastitis in camel have recently been reported in Saudi Arabia (Barbour et al.,1985), Egypt (Mostafa et al., 1987), Somalia (Abdurahman et al., 1991), Ethiopia (Bekele and Molla, 2001), Israel (Guliye et al., 2002) and Kenya (Matofari et al., 2003).

The early detection and treatment of subclinical mastitis greatly reduces the incidence of clinical mastitis. For monitoring mastitis, a number of tests to detect changes in milk can be routinely used for screening purposes in milking herds. One of the screening procedures, for both clinical and subclinical mastitis, involves the measurement of somatic cell counts (SCC) in milk. SCC is a count of the number of neutrophils and normal udder cells present in milk. An increase in the SCC to more than $5 \times 10^{5}$ cells $/ \mathrm{ml}$ is considered to be an indication of udder infection in cattle (Obeid and Bagadi, 1996) and camel (Eberlein, 2007).

In earlier studies, somatic cell contents (SCC), California mastitis test (CMT), Adenosine triphosphate (ATP), N-acetyl-Dglucosamimidase (NAGase) and Serum albumin as been used as indirect diagnostic tools for infected and non-infected quarters of the camel mammary gland (Abdurahman,
1995; Abdurahman et al., 1995; Abdurahman, 1996). However the interpretation of results were problematic because the basal levels of cells and their physiological variations in the camel were and are still not yet established (Abdurahman et al., 1992).

During the past decade there have been several reports on subclinical mastitis in dromedary camels (Obeid, 1983; Arush et al., 1984; Quandil and Oudar, 1984; Barbour et al.,1985; Mostafa et al., 1987) and a few on Bactrian camels (Kospakov, 1976a,b); but little work has been done on subclinical mastitis and the udder's response to bacterial invasion. Barbour et al. (1985) and Saber et al. (2010) applied CMT to composite milk samples from the dromedary camels and concluded that the test was useful for screening subclinical infected udders. Obeid (1983) found a good correlation between the milk leukocyte count and the 'rapid mastitis test'.

In a previous study Abdurahman et al., (1992) have found that Bactrian milk contains not only leukocytes but also large number of a nuclear cell-like particle, so-called 'cell fragments'.

The objectives of this study are to determine the links between SCC, CMT and intramammary infections in apparently healthy camels in order to get references for dromedary species.

\section{Materials and Methods Animals}

Thirty lactating camels (Camelus dromedarius) kept at the farm of Camel and Range Research Center (Al-Jouf, Saudi Arabia) was screened for detection of subclinical mastitis. The camels were of various parities (1 to 8 ) and lactation stages (1-8 months) and suckling their calves. They were housed together and fed with Alfalfa, concentrates and hay. All the camels were free from clinical mastitis during the sampling period.

\section{Sampling procedure}

A total of 120 quarter milk samples from 30 lactating camel were collected. The camel calves were allowed to suckle in order to stimulate milking. The udder and the teats were 
washed and cleaned with $70 \%$ alcohol. The first few strips of milk from each quarter were discarded. About $10 \mathrm{ml}$ of milk was then collected into sterile glass vials. The samples were kept on ice during transportation. The quarter milk samples were subjected to bacteriological isolation and also tested for SCC and CMT respectively

\section{Bacteriological examination}

Milk samples $(0.01 \mathrm{ml})$ from each quarter were streaked on blood agar and MacConkey agar plates; plates were incubated for 24- $48 \mathrm{~h}$ at $37^{\circ} \mathrm{C}$. The plates were then examined for growth colony morphology. Individual colonies were picked for identification according to the Scandinavian recommendations on examination of bovine quarter milk samples (Klastrup, 1975). Muller-Hinton Agar was used for disk diffusion method to test the susceptibility of the isolates to some antibiotic: Oxytetracycline (30ug), Gentamycine (10ug), Ampicilin (10ug), Amoxacillin (25ug), Penicillin (10IU), Colistin sulphate (10ug), Erythromycin (15ug), Sulphamethazol/trimethoprime (25ug). For fastidious organism the Muller-Hiton agar was supplemented with $7 \%$ sheep blood. The interpretation of susceptibility or resistance was done as recommended (Barnes-Pallesen et al., 1987).

\section{California mastitis test (CMT)}

CMT was carried out using the method described by Schalm and Noorlander (1957). An equal volume of CMT reagent and milk was mixed and the reaction was graded 1,2,3,4 or 5, according to the Scandinavian recommendations, corresponding to 0 , trace, 1 , 2 and 3 (Klastrup and Schmidt Madsen, 1974). The test was performed by a trained technician. The reactions were interpreted as follows: score $1=$ no reaction; score $2=$ slight slime which tends to disappear with continued swirling; score $3=$ distinct slime but without gel formation; score $4=$ immediate formation of gel which moves as a mass during swirling; score $5=$ gel develops a convex surface and adheres to the bottom of the paddle.

\section{Somatic cell count (SCC)}

The somatic cell counts (cells $/ \mathrm{ml}$ ) for the quarter milk samples were determined using NucleoCounter SCC-100 (coulter electronic ChemometecA/s, Denmark)

\section{Statistical analysis}

The SCC values were transformed into $\log$ in order to get homogeneous variance. Mean and standard deviation were calculated for quantitative data. The relationships between SCC and CMT were estimated by the correlation of Spearman. The parity effect, the udder localization effect, the type of bacterial contamination effect and the level of CMT reaction were estimated by variance analysis on $\operatorname{logSCC}$. For measuring the parity effect, the variable parity was divided into 3 modalities: primiparous $(n=1)$, second parity $(n=7)$, more than second parity $(n=11)$. The types of bacterial contamination were identified by a Hierarchical Classification Analysis (HCA) after Multiple Correspondence Analysis (MCA). These analyses were applied to a table of presence/absence of different pathogens agents. The software used for data management and statistical analysis was XLSTAT (Addinsoft (C).

\section{Results}

Subclinical mastitis was investigated in a total of 30 lactating camels using SCC, CMT and udder pathogen.

\section{Variability of somatic cell count and CMT}

SCC varied from 9000 to $2,000,000$ cells $/ \mathrm{mm}^{3}$ with an average of 125,000 . On average the left quarters had a higher SCC (Figure 1) than the right ones but differences were not significant. The SCC increased with the parity, passing on average from 24,000 cells $/ \mathrm{mm}^{3}$ in primiparous camel to 98,000 for parity 2 and 157,500 for parity more than 2 , but the difference was not significant also.

The CMT score according to the udder quarter presented similar figure than for SCC: the left quarters are more affected than right quarters by high CMT score ( 1 or 2 ): $26 \%$ for LH and $20 \%$ for LF vs $13 \%$ and $20 \%$ for RH and $\mathrm{RF}$ respectively. 


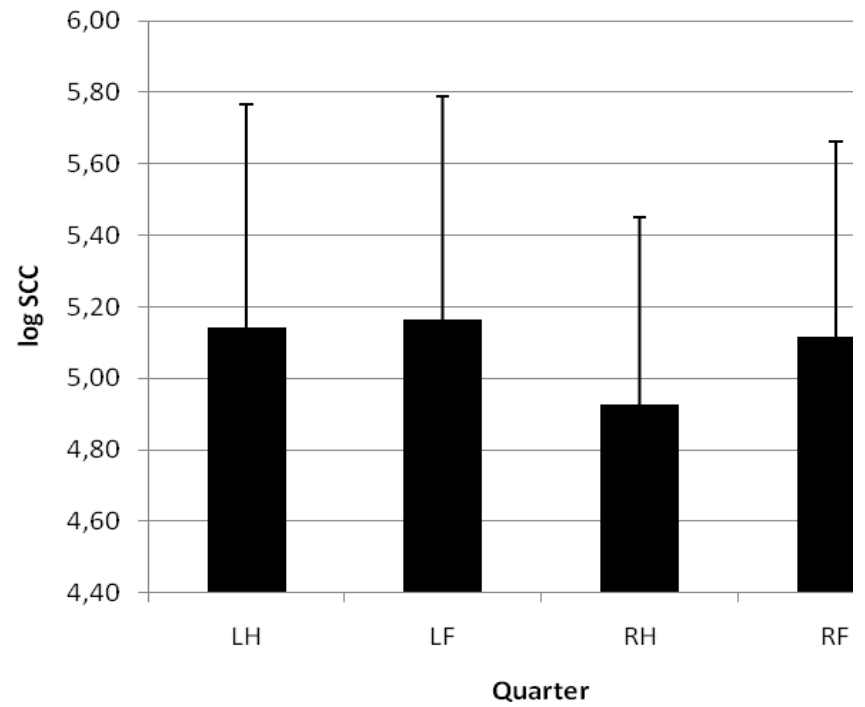

Figure 1. Mean and S.D (error bar) of $\operatorname{logSCC}$ in each quarter of the camel udder.

By adding the score of the four quarters, 5 levels were got from 0 to 4 . The SCC increased significantly with the total importance of CMT level (Table 1)
The highest CMT scores were observed in the front quarters (LF and RF) as shown in Figure 2.

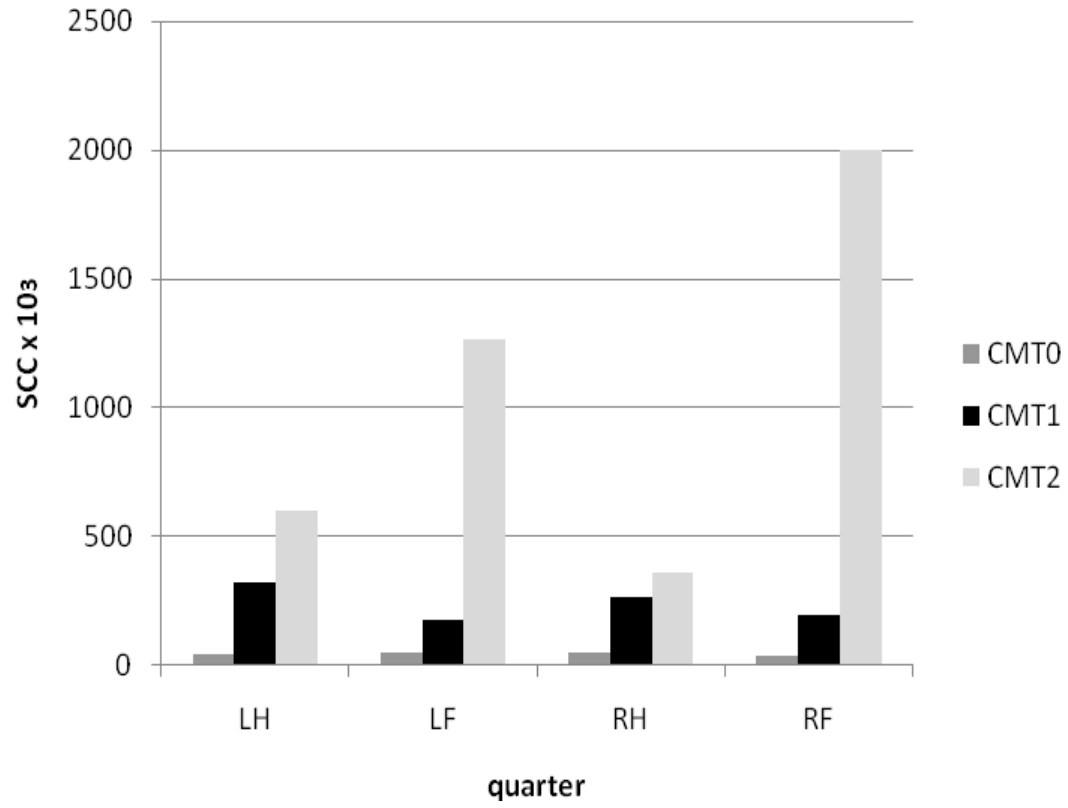

Figure 2. Mean SCC values according to the quarter and to the CMT score in camel milk. 
Emir. J. Food Agric. 2011. 23 (1): 48-58

http://ejfa.info

Table 1. Mean and standard deviation of milk SCC values according to the total CMT score for the four quarters of camel udder.

\begin{tabular}{lll}
\hline CMT score & Mean of milk SCC & SD \\
\hline 0 & $37062 \mathrm{a}$ & 31575 \\
1 & $36442 \mathrm{a}$ & 60462 \\
2 & $121250 \mathrm{~b}$ & 40790 \\
3 & $202916 \mathrm{~b}$ & 99174 \\
4 & $550833 \mathrm{c}$ & 294896 \\
\hline CMT=California mastitis test, SCC=Somatic cell count, SD=Standard deviation &
\end{tabular}

The different letters mean significant difference at $\mathrm{P}<0.001$

\section{The intramammary infection}

Intramammary infections (IMI) were present in most of examined quarter milk samples. The most common bacterium was Streptococcus spp. which was present in $100 \%$ of the samples and in $42.9 \%$ of the isolates (Table 1). Among the major pathogens, E. coli was present in 30\% of the milk samples and represented $12.9 \%$ of the total isolates (Table 2).

Table 2. Distribution of isolates and individual prevalence of bacterial species.

\begin{tabular}{llll}
\hline Bacteria & $\begin{array}{l}\text { No of } \\
\text { isolates }\end{array}$ & \% of isolates & $\begin{array}{l}\text { Individual } \\
\text { prevalence (\%) }\end{array}$ \\
\hline Streptococcus spp. & 30 & 42.9 & 100 \\
S. aureus & 5 & 7.1 & 16.6 \\
Other Staphylococcus & 19 & 27.1 & 63,3 \\
Micrococcus & 4 & 5.7 & 13.3 \\
E. coli & 9 & 12.9 & 30,0 \\
Other Gram negative rods & 3 & 4.3 & 10.0 \\
Total & 70 & 100 & \\
\hline
\end{tabular}

The MCA (Figure 3) showed an opposition between the presence of other Staphylococcus (staph-2) and major pathogens (S. aureus - 2; gram-v-2; microc-2) on the first factor. The presence of E. coli (E. coli - 2) was not well represented on the factorial plan showing independence between IMI by coliforms and the other pathogens.

The classification applied to the bacteria (presence/absence) table allowed to, identify 4 types of bacterial profiles (A) S. aureus only, (B micrococcus associated to S. aureus or with
E. coli, (C) other staphylococcus only, and (D) other staphylococcus associated with E. Coli only or gram negative. The mean SCC is significantly higher in type of profile $\mathrm{B}$ (mean $=226,700)$ than profile $\mathrm{D}(38,400)$ at $\mathrm{P}<0.05$.

By comparing the SCC values according to the isolates, the highest was observed in case of presence of E. coli $(180,000)$ and other staphylococcus $(160,000)$, but the difference with other isolates was not significant (Figure 4). 


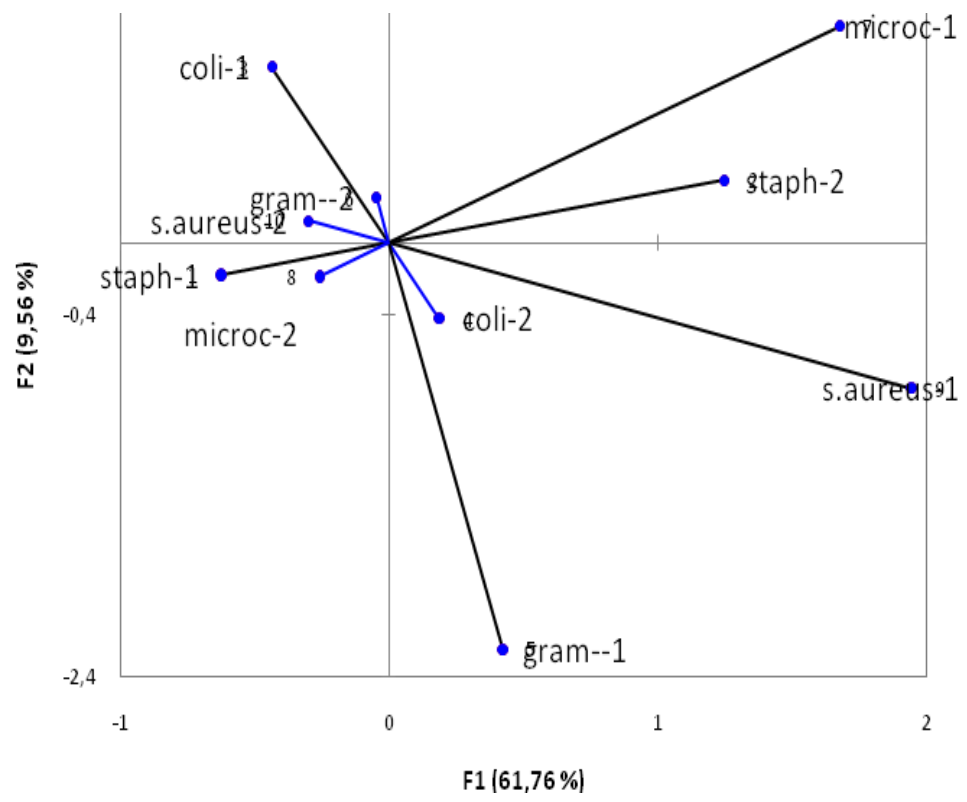

Figure 3. Factorial plan $(1,2)$ from the analysis of a table including the presence (modality 1$)$ or absence (modality2) of the different isolates identified in camel milk.

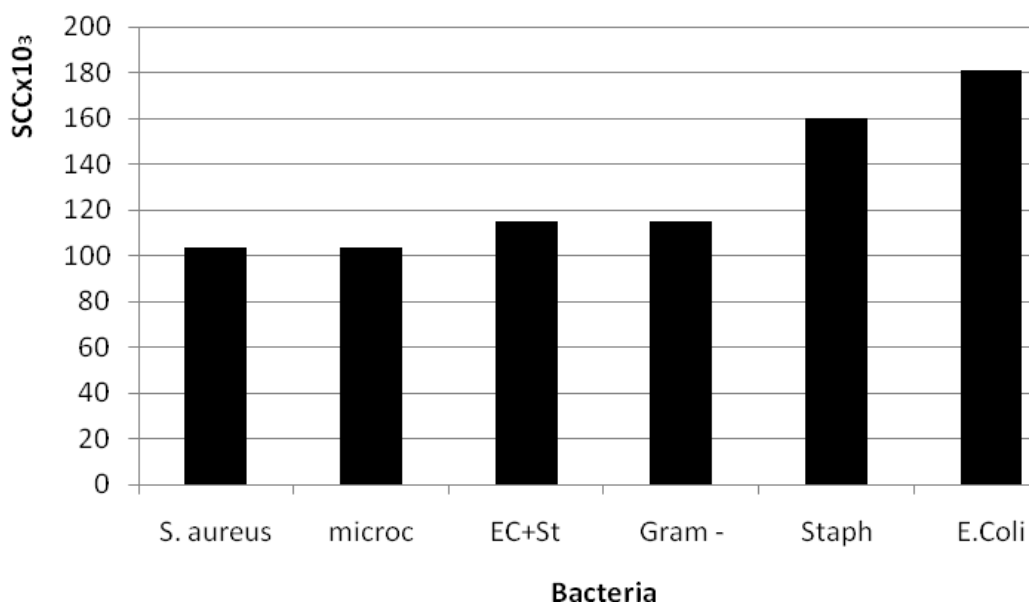

Figure 4. Mean SCC values according to the bacteria isolates in the camel milk.

\section{Sensitivity to antibiotics}

The test on efficacy of various antibiotic on bacterial isolates in camel milk samples (Table 3) revealed that the tetracyclines were still efficient for all the bacteria but resistance was observed mainly with penicillin and in a less extend with gentamycine, colistine sulphate and sulfamids (Table 3 ).

Overall, most isolates and mixed culture were very sensitive to oxytetracycline. 
Emir. J. Food Agric. 2011. 23 (1): 48-58

http://ejfa.info

Table 3. Efficacy of various antibiotics on bacterial isolates from camel milk samples.

\begin{tabular}{|c|c|c|c|c|c|c|c|c|c|}
\hline \multirow{2}{*}{$\begin{array}{l}\text { Bacterial } \\
\text { isolates }\end{array}$} & \multirow{2}{*}{$\begin{array}{l}\text { No of } \\
\text { Sample }\end{array}$} & \multicolumn{8}{|c|}{ Antibiotics } \\
\hline & & AMP & AML & OT & $\mathbf{P}$ & $\mathbf{E}$ & $\mathbf{C N}$ & CT & SXT \\
\hline Streptococcus spp. & 4 & 3 & 3 & 3 & 3 & 3 & 2 & 1 & 0 \\
\hline Staphylococcus spp. & 4 & 2 & 2 & 2 & 1 & 0 & 0 & 0 & 0 \\
\hline E. coli & 4 & 2 & 2 & 2 & 0 & 0 & 1 & 1 & 2 \\
\hline Mixed (Staph.+Strept.) & 4 & 2 & 2 & 3 & 1 & 2 & 2 & 0 & 2 \\
\hline Mixed (Staph.+E.Coli) & 4 & 2 & 2 & 3 & 0 & 1 & 2 & 1 & 3 \\
\hline Mixed (Strept.+E.Coli) & 4 & 2 & 2 & 3 & 0 & 1 & 2 & 1 & 3 \\
\hline
\end{tabular}

$\mathrm{CN}=$ Gentamicin, $\mathrm{CT}=$ Colistin sulphate, $\mathrm{SXT}=$ sulphamethazol/Trimethoprime.

$3=$ very sensitive, $2=$ sestive, $1=$ moderately sensitive, $0=$ Resist.

\section{Discussion}

As for other dairy species, the camel is susceptible to mastitis, especially in case of dairy intensification. In spite of lack of information on epidemiology and pathogenicity of mastitis in camel remains unclear, the SCC is a convenient indicator which is widely used as an indicator of the degree of inflammation of the udder and to predict udder infection (Poutrel and Rainard, 1982).

\section{The SCC and CMT values in camel milk}

The references on SCC in camel milk were recent and not common. According to Merin et al., (2004), the SCC values in infected udder are lower in camel compared to the other ruminants (Table 4). Except for one of our sample with CMT score up to 2 in 2 quarters, the infected quarter rarely over passed 500,000 cells $/ \mathrm{m}^{3}$. Elsewhere, the N-acetyl- $\beta-\mathrm{D}$ glucosaminidase (NAGase) which is used as indicator of IMI in cow (NAGase is positively correlated to IMI and to SCC) has quite different values in camel milk and there was no difference according to the infection status of the camel udder contrary to cow (Table 4).

Table 4. Compared values in SCC and NAGase activities in different dairy species (from Merin et al., 2004).

\begin{tabular}{|c|c|c|c|c|}
\hline & \multicolumn{2}{|l|}{ SCC } & \multicolumn{2}{|l|}{ NAGase } \\
\hline & Non infected & Infected & Non infected & Infected \\
\hline Camel & 118,000 & $308,000 *$ & 96 & 89 \\
\hline Cow & 100,000 & $>1,000,000$ & 18 & 60 \\
\hline Ewe & 374,000 & $3,272,000$ & 38 & 77 \\
\hline Goat & 485,000 & $2,203,000$ & - & - \\
\hline
\end{tabular}

An increase in the number of somatic cells in camel milk with infected quarter has been reported also by Mostafa et al. (1987). The increase of SCC or mastitis with the age of dairy animals or parity was widely observed in cow (Faye et al., 1986). The cause of this increasing could be linked as well to a less immunity defense, to a change in udder morphology (higher elasticity of mammary gland) and to the increasing of udder trauma with the number of parities.
The higher SCC values observed in the left quarters and CMT scores in front udder is different usually than in cow where the hind quarters are the most exposed to infection (Lancelot et al., 1997). Probably the anatomy of camel with a narrow basin could explain a better protection of the hind quarters compared to the front ones.

CMT is the most indirect test used to detect subclinical mastitis as the degree of gel 
formation is related with the number of cells in milk.

Positive correlation of CMT with the presence of mastitis pathogens in camel milk and SCC values showed that CMT is useful screening test in the detection of mastitis in camel and may serve to segregate udder infected with major pathogen in a subclinical form (Abdurahman, 1996). The relations between high CMT score, elevated SCC and presence of bacteria in milk samples was clearly attested in our study.

\section{The intramammary infections in camel milk}

Gram-positive Cocci were the dominant udder pathogen isolated in our study, and regarded as important mastitis pathogens in camel (Barbour et al., 1985; Mostafa et al., 1987).

Agent found in positive culture like $S$. aureus and other species of Staphylococci were mainly responsible for subclinical mastitis, but some agents, like Strept. agalactiae were found in both clinical and subclinical mastitis

As described by Younan et al. (2001), the prevalence of Staphylococci varies according to different studies, but there is nearly no publication on bacteriological hygiene of milk where Staphylococci are not mentioned (Eberlein, 2007). E. coli and other Coliforms provoked generally a higher udder reaction with a higher SCC and CMT score but in a very short duration as they are rapidly destroyed by inflammatory reactions (Philipot et al., 1995)

\section{Antibiotic resistance}

There are growing concerns regarding the increased prevalence of antimicrobial resistance worldwide (WHO, 2001). The use of large amount of antimicrobial drugs for disease control in food-animal production is suspected to play a role in the spread and persistence of antimicrobial-resistant zoonotic bacteria (Witte, 1998). In the present study, all isolates were found to be sensitive to most available antimicrobial drugs like oxytetracycline, ampicillin, amoxicillin but Streptococcus spp. showed resistance to sulfamids, Staphylococcus spp. and E.coli to different antibiotics, particularly penicillin which was widely used in veterinary medicine. This agrees with Mekonnen et al. (2005) reported antibioresistance of IMI pathogens to two or more antibiotics by some bacterial isolates in cow milk. No data was available at our knowledge for camel milk.

\section{Conclusion}

SCC values and CMT scores could be used by routine for detecting subclinical mastitis in camel milk as for other dairy animals in spite of an apparently lower reaction compared to cow and small ruminants. Elsewhere, the probable development of milking machine could increase the risk of udder inflammation and infection in camel in Saudi Arabia. The bacteria revealed by this study could be a possible cause of subclinical mastitis in dromedary camel. Therefore, the frequency of camel mastitis in Saudi Arabia is likely remaining unless appropriate management strategies are adopted. This could be based on a combination of frequent milking with occasional testing of milk and rational use of antimicrobials in the treatment of clinical cases. Frequent milking of lactating camel with occasional testing of milk would lead to early detection and treatment of subclinical mastitis while culling of chronic cases would reduce the prevalence and spread of these conditions.

\section{Acknowledgements}

This study has been achieved within FAO project UTF/SAU/021/SAU with the support of Camel and range research Center (CRRC). The authors thank Mr Sallal Issa Al-Mutairi, head of the CRRC for his encouragements and support.

\section{References}

AbdelGadir, A. E., G. Hildebrandt, J. N. Kleer, B. Molla, M. Kyuleand and M. P. Baumann. 2006. Comparison of California Mastitis Test (CMT), Somatic Cell Count (SCC) and bacteriological examinations for detection of Camel (Camelus dromedarius) mastitis in Ethiopia. Berl. Munch. Tierarztl. Wochenschr. 119:45-49.

Abdurahmann, O. A. S., S. Bornstein, K. S. Osman, A. M. Abdi, and G. Zakrisson. 1991. Prevalence of mastitis among camels 
in South Somalia: a pilot study. Mogadishu, Somalia, Somali Acad. Arts and Sci., p. 1-9 (Camel forum working paper 37)

Abdurahmann, O. A. S., R. Cooray and S. Bornstein. 1992. The ultrastructure of cells fragments in mammary secretions of Camelus bactrianus. J. Vet. Med. A 39:648-655.

Abdurahmann, O. A. S. 1995. N-acetyl-B-Dglucosaminidase and serum albumin as indicatiors of subclinical mastitis in the Camel. J. Vet. Med. A. 42:643-647.

Abdurahmann, O. A. S. 1996. The detection of subclinical mastitis in the Bactrian camel(Camelus bactrianus) by somatic cell count and California mastitis test. Vet. Res. Comm. 20:9-14.

Abdurahmann, O. A. S., H. Ageb, B. Abbas and G. Astron. 1995. Relations between udder infection and somatic cells in camel (Camelus dromedarius) milk. Acta Vet. Scand. 36:648-655.

Arush, M. A., C. Valente, M. Compagnucci and H. Hussein. 1984. Studies on the prevalence of mastitis in the dromedary (Camelus dromedaries) in Somalia. Bull. Sci. Fac. Zootech. Vet., Univ. Nazionale Somalia 4:99-104.

Barbour, E. K., N. H. Nabbut, W. M. Frierichs, H. M. Al-Nakhli and A. A. Al Mukayel. 1985. Mastitis in Camelus dromedarius in Saudi Arabia. Trop. Anim. Health Prod. 17:173-179.

Barnes-pallesen, F. D., P. Blackmer, A. Britten, B. R. Bushnell, M. D. Van Damme and F. Wellcome. 1987. Laboratory and field handbook on Bovine mastitis. Vol.1:3-208. Arlington VA, USA; NMC inc.

Bekele, T. and B. Molla. 2001. Mastitis in lactating Camels (Camelus dromedarius) in Afar Region, north-eastern Ethiopia. Berl.Munch. Tierz. Woch. 114(5-6):169172.

Eberlein, V. 2007. Hygienic status of camel milk in Dubai (United Arab Emirates) under tow different milking management systems. Doctorate thesis, veterinary faculty, Ludwig-Maxmillians-Universitat Munchen, $120 \mathrm{pp}$.

Faye, B., J. C. Fayet, M. Genest, and M. Chassagne. 1986. Enquête écopathologique continue: 10. Variations des fréquences pathologiques en élevage bovin laitier en fonction de la saison, de l'année et du numéro de lactation. Ann. Rech. Vét. 17:233-246.

Faye, B. 2005. Productivity potential of camels. Proc. of Intern. Workshop, «Desertification combat and food safety: the added value of camel producers". Ashkhabad (Turkmenistan), 19-22 april 2004. In "Vol. 362 NATO Sciences Series, Life and Behavioural Sciences". B. Faye and P. Esenov (Eds), IOS press Publ., Amsterdam (The Netherlands) 127-134.

Fthenakis, G. C. and J. E. T. Jones. 1990. Subclinical mastitis and milk loss. Brit. Vet. J. 146:43.

Guliye, A. Y., C. Van Creveld and R. Yagil. 2002. Detection of subclinical mastitis in dromedary camels (Camelus dromedarius) using somatic cell counts and the N-acetylbeta-D-glucosaminidase test. Trop. Anim. Htlh. Prod. 34(2):95-104.

Kalla, D. J. U., I. S. R. Butswat, S. T. Mbap, A. M. Abdussamad, M. S. Ahmed and I. Okonkwo. 2008. Microbiological Examination of camel (Camelus dromedarius) milk and sensitivity of milk microflora to commonly available antibiotics in Kano, Nigeria Sav. J. Agric. $3: 1-8$.

Klastrup, O. 1975. Nordic recommendations of quarter milk samples. Annu. Bull. Int. Dairy Fed. 85:41-52.

Klastrup, O. and P. Schmidt Madsen, 1974. Nordiske rekommendationer vedrorende mastitisundersogelser af kirtelprover (Nordic recommendations concerning mastitis control of quarter samples). Nord. Vet. Med., 26:197-204. 
Kospakov, Z. K. 1976a. Cell content in the milk of Bactrian camels depending on stage of lactation and condition of the udder. Problemy Veterinarnoi Sanitarii, 55:21-25 (in Russian). Vet. Bull.,48 (11) $\mathrm{N}^{\circ} 1566$ (1978)

Kospakov, Z. K. 1976b. Phage typing of pathogenic Staphylococci isolated from milk and the environment of camel breeding farm. Problemy Veterinarnoi Sanitarii, 55:32-35 (in Russian). Vet. Bull.,48 (11)N6559 (1978)

Lancelot R., B. Faye and F. Lescourret. 1997. Factors affecting the distribution of clinical mastitis among udder quarters in French dairy cows. Vet. Res. 28:45-53.

Matofari, J. W., Y. Mario, E. W. Mwatha and P. O. Okemo. 2003. Microorganisms associated with subclinical mastitis in Kenyan camels (Camelus dromedarius). J. Trop. Microbiol. 2:11-16.

Mekonnen, H., S. Workineh, M. Bayleyegn, A. Mogesand and K. Tadele. 2005. Antimicrobial susceptibility profile of mastitis isolates from cows in three major Ethiopian dairies. Rev. Med. Vet. 156(7):391-394.

Merin U., S. Sela, B. Rosen, R. Pinto and G. Leitner. 2004. Standards for camel milk. Proc. Intern. Workshop, Desertification combat and food safety: the added value of camel producers". Ashkabad (Turkmenistan), 19-22 April 2004. In "Vol. 362 NATO Sciences Series, Life and Behavioural Sciences". B. Faye and P. Esenov (Eds), IOS press Publ., Amsterdam (The Netherlands), 152-158.

Mostafa, A. S., A. M. Ragab., E. E. Safwat, Z. El-Sayed, M. Abd-el-Rahman, N.A. ElDanaf and M. T. Shouman. 1987. Examination of raw she-camel milk for detection of subclinical mastitis . J. Egyp. Vet. Med. Assoc. 47:117-128.

Obeid, A. I. 1983. Field investigation, clinical and laboratory findings of camel mastitis. M.Sc. Thesis, University of Khartoum (Sudan), 50 p.
Obeid, A. I. and H. O. Bagadi. 1996. Mastitis in Camelus dromedarius and the somatic cell count of camel's milk. Res. Vet. Sci. 61:55-58.

Philipot, J. M., B. Faye and G. Peretz. 1995. Modifications de l'épidémiologie des infections mammaires des vaches laitières, induites par les programmes de lutte. Renc. Rech. Ruminants. 2:295-298.

Poutrel, B. and P. Rainard. 1982. Predicting the probability of quarter infection (by major pathogens) from somatic cell concentration. Am. J. Vet. Res. 43:1296.

Quandil, S. S. and J. Oudar. 1984. Bacteriological study of some cases of mastitis in the dromedary (Camelus dromedarius) in the United Arab Emirates. Preliminary report. Rev. Med. Vet. 135:705-707.

Saber, K., S. Mohammed and A. Ahmed. 2010. Sanitary conditions of lactating dromedary she-camel environment with special reference to milk quality and subclinical mastitis monitoring. Emir. J. Food Agric. 22(3):207-215.

Schalm. O. W. and D.O. Noorlander. 1957. Experiments and observations leading to development of California mastitis Test. J. Am. Vet. Med. Asso. 130:199-204.

Schwartz, H. J. and M. Dioli. 1992. The Onehumped Camel in Eastern Africa: A pictorial guide to Diseases, Health Care and Management. Verlag Joseph Margraf Publ. Germany, 282 p.

Tibary, A. and A. Anouassi. 2000. Lactation and udder disease. In: L. Skidmore and G.P. Adams (Eds.). Recent Advances in Camelid Reproduction. International veterinary Information Service (www.ivis.org), accessed March 13 ${ }^{\text {th }}, 2005$.

WHO, 2001. World Health Organization: global strategy for containment of antimicrobial resistance. World health organization department of communicable disease surveillance and response. WHO/CDS/CRS/2001.2. WHO, Geneva, Switzerland. 
Emir. J. Food Agric. 2011. 23 (1): 48-58

http://ejfa.info

Witte, W. 1998. Medical consequences of antibiotic use in agriculture. Sci. 279:996997.
Younan, M., Z. Ali., S. Bornstein and W. Muller. 2001. Application of the California mastitis test in intramammary Streptococcus agalactiae and Staphylococcus aureus infections of camels (Camelus dromedarius) in Kenya. Prev. Vet. Med. 51:307-316. 